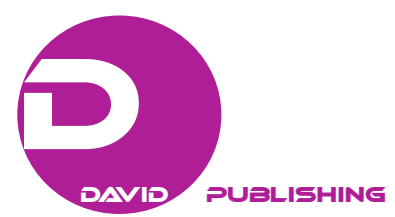

\title{
Back Finance: Financial Derivatives and 2008 Process
}

\author{
Gürhan Uysal \\ Ondokuz Mayıs University, Samsun, Turkey
}

\begin{abstract}
First of all, this paper explores monetary perspectives of Keynes and Friedman. Secondly, it explores financial derivative system in global economy. Thirdly, this study explores world money notion of M. Keynes. Keynes presented world money concept in 1944, in Bretton Woods Talk. His notion may be applied through global GDP today. Assumption of this study is that world money may finance debt payment of nations, and it finances balanced payment deficit of economies, because capitalism of modern economy requires money to run business system. Uysal (2016) presented World money Notion and 2008 Process in conference of 11th International Silkroad in Tbilisi, Georgia. Uysal $(2015,2016)$ discussed World Money concept in the conference with assumption that it may increase demand in global economy. This study is based on case study, which is 2008 Global Crise. Because its effect continues worldwide.
\end{abstract}

Keywords: Back Finance Methodology, Financial Derivatives, J. M. Keynes, World Money, IMF, arbitrage

\section{Introduction}

Money is requirement of capitalism. If there is no money, crises of capitalizm start. Because market and firms need money for sales. If there is money in business markets, there are demand and sales, and sales strengthen production activity of firms. For example, professor Wasily Lentief emphasizes that notion with his input-output table. Accordingly, if there is sale in output line, there would become production in input line. Thus, markets need money for demand.

Problem of global economy might be total demand issue. Deflation appears on economies due to lessening demand. There are mass production and lots of products in markets. Therefore, markets need monetary to increase demand in markets. This study aims to discuss World money Notion of J. M. Keynes to increase total demand in economies. Keynes aimed to increase total demand in economies. First of all, Keynes presented IS-LM policy; secondly, Keynes suggested world money in IMF. World Money policy continues as SDR in IMF.

\section{Back Finance (or Reverse Finance) Methodology}

This paper explores 2008 Process with financial derivatives. George Soros, investor, warns of that 2008 process up again, 1990s witnessed financial innovations such as option, swap, future, forward, etc. Those are called as financial derivatives. Financial derivatives resulted in financial baloon during 2000s. There are two

This paper is presented at 11 th Silkroad International Conference, International Blacksea University, Tbilisi, Georgia, May 20-22th, 2016.

Gürhan Uysal, associate professor/Ph.D., School of Business, Ondokuz Mayis University, Samsun, Turkey.

Correspondence concerning this article should be addressed to Gürhan Uysal, School of Business, Ondokuz Mayis University, Kurupelit Campus, 55139, Atakum-Samsun, Turkey. 
reasons for 2008 global crise. They are financial baloon and mortgage baloon. Because 2008 has recession problem. Reason might become those baloons.

George Soros stresses that, new global crises are upcoming, maybe. What would be? What if derivatives create baloon and recessions again? Back Finance methodology may be used to stop upcoming crises. Fed financed USA banks in 2008 process. According to back finance policy, FED may have financed Europe banks. It is backfinance. So, USA Fed may finance Japanese banks to hinder new crises. In this chain, Japanese would make its payment to European investors, and Europeans make its payment to USA investors. Thus, new financial crises and possible recession may stop. There might be two channels of derivatives in global economy:

(1) USA-Europe-Asia (Japan)

(2) USA-Europe-Africa

Financial innovations are made mostly in USA in 1990s and in Europe. Thus, FED may apply back finance according to those chains. In 3rd quarter of 2008, FED financed US banks with 700 billion dollars. Instead, he may have financed African or Asian financial banks, and Africans would make payments to Europe, and European would make it to USA banks, and they don't need to obtain their receivable from US banks. Hence, currently, FED may finance Japanese banks to stop new upcoming crises. To conclude, back finance methodology may be used for global economy to prevent economies from upcoming crises.

\section{Monetary Perspectives of Keynes and Friedman}

There are two people of modern economy in 20th century: Keynes and Friedman. This paper explores their monetary policy perspectives. According to market theory, business markets need money for creating demand. For example, GDP per capita represents total demand in macro economy. GDP per Capita of Turkish Economy increased five triples between 2002 and 2010. Thus, total demand in economy increased. Backhouse and Bateman (2008) say that Keynesian monetary aims to supply markets with money through public investment. This policy is called as IS-LM. IS-LM is presented by economists, John Hicks in 1937 after presentation of General Theory of Keynes in 1936. Major policy of Keynes is budget deficit policy. This policy is implemented in global economy in 1950s; however, it resulted in hyperinflation in 1970s. Cause and effect analysis is an important analytical method in economy field. Thus, Keynesian economy attracted critics from politics and academy. There might be three reasons of 1970's stagflation: 1950s large budget deficit policy, 1967 Vietnam War, and 1973 Oil Crisis.

Milton Friedman criticised Keynesian monetary system in 1970s (Skousen, 2014). He assumed that overmoney supply results in inflation in economy. Central Bank must become independent to stop government's force of overmoney supply. Because Friedman assumes that budget deficit policy generates overmoney supply in economy.

Uysal (2016) presented World Money Notion and 2008 Process in conference of 11th International Silkroad in Tbilisi, Georgia. Uysal $(2015,2016)$ discussed World money concept in the conference with assume that it may increase demand in global economy. This study is based on case study, which is 2008 Global Crisis. Because its effect continues world wide. 2008 is recession crises, and it turned to a debt crisis later. For example, debt/income ratio of England becomes $150 \%$ in this process.

Main research result might be that World money of J. M. Keynes is applied through global GDP dimension by IMF. It is 60 trillion USD currently, and 10\% percent of GDP might become print rate of World 
money. Further, that monetary might continue in global economy thorugh next 10 years. Secondly, economies may apply back finance policy to stop possible effect of financial derivatives in global economy.

\section{Discussion: Theory of Market, Demand, Monetary}

\section{Market Theory}

Markets need money to increase demand, according to market theory. That policy is requirement of capitalism. Factory system is established for businesses in Industrial Revolution, and capitalism started with Industrial Revolution. Main result of factory system is mass production and scale of economies. Mass production needs consumption and demand. If there isn't demand, there wouldn't become production in the firm, and it will generate unemployment. Therefore, J. M. Keynes targeted for increasing total demand in economies. Market theory says that, money results in demand in market. Market theory claims that market needs money for demand. Model is:

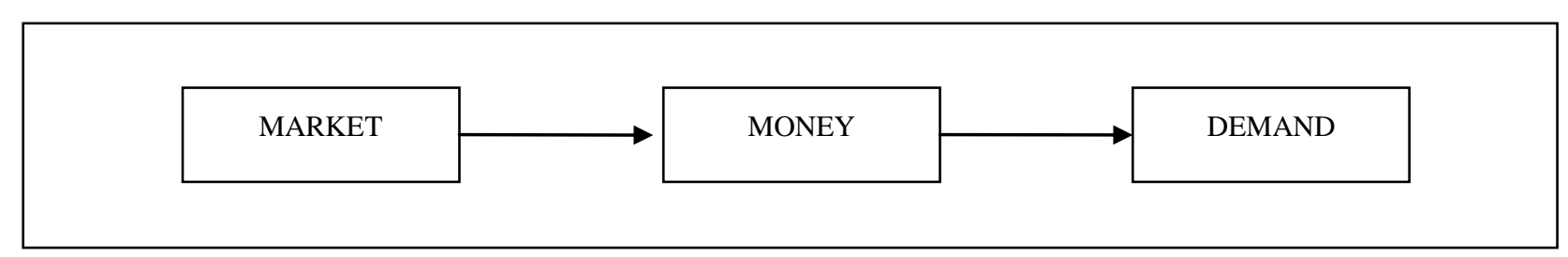

Figure 1. Market theory.

Thus, IMF may adopt "world money" concept to increase total demand in world economy. World Money concept is presented by J. M. Keynes in establishment of IMF in 1940s. Its name is "bancor". However, world money is applied by IMF as SDR notion currently. It is abbreviation of special drawing rights. Aim of SDR is to finance balanced payment deficits of national economies. Thus, World Money may replace SDR system of IMF as a new currency common. Because world money may supply markets with money to increase demand.

\section{World Money Notion of Keynes}

However, equality of world money might become "global GDP" quantity. Global GDP is 60 trillion dollars in global economy, $10 \%$ of global GDP might become quantity of world money. Thus, IMF may print 10 trillion dollars each year to finance balanced payment deficit of national economies. World Money concept of IMF may be sustained through next 50 years in global economy. Continued, the print of money each year may increase total demand in global economy. Because deflation appears on economy due to lack of money and lack of demand. Global economy currently has two faces: isomorphism and full competitive structure. Those two factors lead to deflation in economies.

Second dimension of World Money is quota. Each country may have a quota in IMF in World money system. It withdraws dollar as a world money when needing money for financing balanced deficit. For example, suppose Turkey has one billion dollar account (or quota) in IMF, and Turkey needs 10 million dollars in financing balanced payment deficit. Thus, it withdraws 10 million from its quota at IMF. Finally, this study assumes that small countries need world money for financialization. Hence, IMF may print USD as a world money.

\section{Process of 2008 Global Crisis}

Monetary Policy could be applied in 2008 crisis process. There are two reasons of 2008 crisis, the process 
of which is deep as much as 1929 Crisis. There are three economic crises in World economy: 1873, 1929, and 2008. All are USA emerged. Property of USA crises is long lasting and deeper, and affects society long time. In 1929, economies applied Keynesian Policy of IS-LM. In 2008, economies may be applied monetary policy. Financial balloon and mortgage baloon of 2000s may result in 2008 process. In this case, FED may apply backfinance methodology. He may support European banks or Asian banks to stop upcoming crise instead of supporting only American banks. Because mortgage baloon exploded before 2008, they couldn't pay its mortgage payment, and financial derivatives chain was broken. Global Crisis of 2008 continues as glocal at this moment. Because Turkish Economy, European Economy, and Asian Economy have economic dilemmas. Either, USA economy experiences for deflation issue.

\section{Institutional Golden Theory: Arbitrage}

USA economy has two points: institutional economy and classical economic view. Institutional Golden theory is based upon those opinions. Accordingly, an institution will print golden, and will print USD, and it distributes dollars into global economy. That institution might become a financial bank in Washington D.C., USA. This financial bank would print golden, and it would print US Dollar, and the bank would distribute it into global economy. USA Fed applied similar policy during 2008 as quantity enlargement policy. Therefore, the financial bank may finance global economy with US dollars. Arbitraj Pricing Theory may boost financial investments; for example, USA prints 1,000 \$ golden in his country, it may make 100,000 arbitrage in Japan. Arbitrage Pricing theory takes advantage of price differences among national economies. Further, suppose dolar value is 3 TL in Turkey, and 4 unit in Nigeria, and 10 in Russia. A financial investor, such as HSBC investor, takes advantage of arbitrage. It invests in Turkey, then investor goes to Nigeria, then goes to Russia. And it may increase its financial value of beginning capital. In this financial policy, an investor, bank, prints golden in USA, and prints US dollar in USA, equals to golden value. Investor takes advantage of arbitrage price diffrences. And this chain ends in Japanese economy.

Institutions manage the economy, according to institutional economy. Thorsten Veblen and James Buchanan, professors, are founder of institutional economy principles. For example, global politics are dominated by USA government after World War II. USA appeared on policy after World War I. And USA government manages the world economy and politics by institutions such as WTO, IMF, UN, World Bank. For example, WTO — World Trade Organization — manages globalization moves in world economy.

\section{Conclusion}

Akalin (2014) suggests that markets need money for demand. It is essential of this study. Currently, world economy has two perspectives: full competitive market and isomorphism. Thus, firms experience demand problems in markets. Isomorphism is that products are resemble each other in market. Therefore, consumers have troubles for product choices. This paper suggests that world money policy may increase total demand in economies for firms' products.

According to Hunt (2002), crises of modern economy, or capitalism, appear in economy due to lack of money in markets. If money disappears from economy, crises of economy start such as recession problem. Global economy improves economic solutions for money problem of global economy. It may be world money notion against monetary problem of global economy. Solution of IMF might become world money with quantity of global GDP. 


\section{References}

Akalın, G. (2014). Market economy of Turkey. Ankara: Orion Publishing.

Backhouse, R. E. , \& Bateman, B.W. (2008). Keynes. Ankara: Orion Publishing.

Hunt, E. K. (2002). History of economic thought. Ankara: Orion Publishing.

Skousen, M. (2014). History of Economic Thought. Ankara: Orion Publishing.

Uysal, G. (2015). Golden quantity theory: Against monetarist school. 10th International Silkroad Conference, International Blacksea University, Tbilisi, Georgia, May 22-24th.

Uysal, G. (2016). Back finance: Financial derivatives and 2008 process. 11th International Silkroad Conference, International Blacksea University, Tbilisi, Georgia, May, 20-22th. 